\title{
MANAJEMEN TENAGA KEPENDIDIKAN FAKULTAS EKONOMI DAN BISNIS USU DALAM MENDUKUNG PENCAPAIAN STANDAR NASIONAL PENDIDIKAN
}

\author{
Erjan Fikry Antari ${ }^{1}$ \\ M. Dian Wahyudi ${ }^{2}$ \\ erjan.gt@gmail.com ${ }^{1,}$ diahdian88@gmail.com ${ }^{2}$ \\ Administrasi Pendidikan, STKIP Budidaya Binjai, \\ Jl. Gaharu No. 147, Jatimakmur, Binjai Utara, Jati Makmur, Binjai, Kota Binjai, Sumatera Utara \\ 20746
}

\begin{abstract}
ABSTRAK
Tujuan penelitian ini untuk mengetahui seberapa baik tingkat penilaian Manajemen Tenaga Kependidikan FEB USU dalam Mendukung Pencapaian Standar Nasional Pendidikan berdasarkan Buku VI Matrik Penilaian Borang dan Evaluasi Diri, Badan Akreditasi Nasional Perguruan Tinggi Jakarta 2011, yang berhubungan dengan Tenaga Kependidikan. Penelitian ini bersifat deskriptif dan verifikasi. Waktu penelitian dimulai dari Mei sampai dengan Juli 2019. Populasinya adalah seluruh tenaga kependidikan di lingkungan Fakultas Ekonomi dan Bisnis USU. Penelitian ini menggunakan beberapa variabel yang terdiri dari Standar Nasional Pendidikan sebagai variabel terikat, peraturan dan kebijakan fakultas, serta implementasinya sebagai variabel moderating, dan pencapaian nilai Standar Nasional Peneididikan sebagai variabel bebas. Hasil penelitian menunjukkan 1. Berdasarkan 18 indikator penilaian yang menggunakan poin-poin pada Instrumen Akreditasi Perguruan Tinggi BAN-PT, Buku VI, Matrik Penilaian Borang dan Evaluasi Diri, Badan Akreditasi Nasional Perguruan Tinggi, Jakarta 2011, pada poin-point yang berhubungan dengan manajemen tenaga kependidikan, dihasilkan penilaian kebijakan FEB USU sebesar 41 dari maksimal 72 poin (rata-rata 2,28 poin/ cukup), dan nilai penilaian implementasi kebijakan FEB USU sebesar 16 poin dari maksimal 68 poin (rata-rata 0,94/ kurang). 2. Berdasarkan hasil penilaian disimpulkan bahwa manajemen tenaga kependidikan FEB USU dalam mendukung pencapaian standar nasional pendidikan cukup dalam kebijakan namun kurang dalam implementasi. 3. Rendahnya komitmen para pengambil kebijakan di lingkungan FEB USU dalam mewujudkan visi, misi, renstra dan renop FEB USU, khususnya yang berhubungan dengan tenaga kependidikan.
\end{abstract}

Kata kunci : Manajemen Tenaga Kependidikan, Standar Nasional Pendidikan 


\section{Jurnal Serunai Administrasi Pendidikan}

Vol 9, No. 1, Maret 2020

e-ISSN 2620-9209

\section{PENDAHULUAN}

Sebagaimana dicantumkan dalam pembukaan dan batang tubuh UUD 1945, pemerintah diamanatkan untuk mencerdaskan kehidupan bangsa melalui sistem pendidikan nasional. Sistem pendidikan nasional diharuskan mampu menjamin pemerataan kesempatan pendidikan, peningkatan mutu serta relevansi dan efisiensi manajemen pendidikan untuk menghadapi tantangan sesuai dengan tuntutan perubahan kehidupan lokal, nasional, dan global sehingga perlu dilakukan pembaharuan pendidikan secara terencana, terarah, dan berkesinambungan. Untuk mewujudkan hal tersebut, maka diperlukan suatu standar atau kriteria minimal tentang sistem pendidikan yang berlaku di seluruh wilayah hukum Negara Kesatuan Republik Indonesia.

Pendidikan tinggi sebagai bagian dari sistem pendidikan nasional memiliki peran strategis dalam mencerdaskan kehidupan bangsa dan memajukan ilmu pengetahuan dan teknologi dengan memperhatikan dan menerapkan nilai humaniora serta pembudayaan dan pemberdayaan bangsa Indonesia yang berkelanjutan. Pendidikan tinggi juga diharapkan mampu mengembangkan ilmu pengetahuan dan teknologi serta menghasilkan intelektual, ilmuwan, dan/atau profesional yang berbudaya dan kreatif, toleran, demokratis, berkarakter tangguh, serta berani membela kebenaran untuk kepentingan bangsa dengan tujuan meningkatkan daya saing bangsa dalam menghadapi globalisasi di segala bidang.

Untuk mewujudkan keterjangkauan dan pemerataan yang berkeadilan dalam memperoleh pendidikan tinggi yang bermutu dan relevan dengan kepentingan masyarakat bagi kemajuan, kemandirian, dan kesejahteraan, diperlukan penataan pendidikan tinggi secara terencana, terarah, dan berkelanjutan dengan memperhatikan aspek demografis dan geografis. Evaluasi, akreditasi, dan sertifikasi dibutuhkan untuk penjaminan dan pengendalian mutu pendidikan sesuai dengan Standar Nasional Pendidikan. Untuk itu dibentuklah Badan Akreditasi Nasional Perguruan Tinggi (BAN-PT) selaku badan evaluasi mandiri yang bertugas menetapkan dan menilai kelayakan program dan/atau satuan pendidikan pada jenjang Pendidikan Tinggi berdasarkan kriteria yang telah ditetapkan dengan mengacu pada Standar Nasional Pendidikan.

Menurut Mulayu S. P. Hasibuan manajemen merupakan alat untuk mencapai tujuan yang diinginkan. Dengan manajemen, kinerja sebuah organisasi dapat berjalan secara maksimal. Demikian juga dengan lembaga pendidikan. Dengan manajemen yang baik, maka sebuah institusi pendidikan akan dapat berkembang secara optimal sebagaimana yang diharapkan. Manajemen pendidikan yang baik memerlukan sebuah perencanaan, pelaksanaan dan pengawasan yang baik agar proses pendidikan berjalan dengan maksimal.

Menurut Peraturan Menteri Pendidikan dan Kebudayaan Republik Indonesia Nomor 49 tahun 2014 Tentang Standar Nasional Pendidikan Tinggi, Tenaga kependidikan adalah anggota masyarakat yang mengabdikan diri dan diangkat untuk menunjang penyelenggaraan pendidikan tinggi antara lain, pustakawan, tenaga administrasi, laboran dan teknisi, serta pranata teknik informasi. Tidak bisa dipungkiri bahwa tenaga kependidikan berperan penting dalam laju organisasi suatu lembaga pendidikan.

Fakultas Ekonomi dan Bisnis (FEB) USU yang berdiri sejak 1 Oktober 1961 menyelenggarakan dan mengembangkan pendidikan mulai dari Program Studi D3, S1, S2 sampai dengan S3 dengan kurikulum terkini guna membekali mahasiswa dengan pengetahuan dan keahlian sehingga dapat menghasilkan lulusan yang professional. FEB USU terus 
berbenah dalam upaya meningkatkan kualitas serta kinerjanya melalui peningkatan kualitas administrasi pendidikan dan berupaya meningkatkan predikat akreditasi pada seluruh program studinya. Pedoman dan arah seluruh program, aktivitas dan kegiatan yang direncanakan dan akan dilakukan dituangkan dalam rencana strategis FEB USU 2015 -2019.

Para pengambil kebijakan FEB USU menyadari bahwa kualifikasi pendidikan, kompetensi, etos kerja, dan integritas tenaga kependidikan FEB USU masih rendah. Pelatihan-pelatihan yang diberikan masih belum efektif meningkatkan kompetensi yang dibutuhkan. Sebaran tenaga kependidikan juga tidak sesuai dengan kebutuhan yang berakibat kepada pelayanan yang tidak optimal. Sehingga diperlukan pemetaan tenaga kependidikan yang meliputi kebutuhan, kompetensi, dan deskripsi kerja untuk membuat kebijakan yang tepat dalam rekrutmen dan sistem penghargaan. Permasalahan-permasalahan ini tertuang dalam Renstra FEB USU tahun 2015-2019.

Sebagai bagian dari tenaga kependidikan FEB USU, peneliti mendapati ketidaksesuaian kebijakan yang diambil oleh pengambil kebijakan dengan kebijakan yang di tuangkan dalam Renstra maupun Renop FEB USU Tahun 2015-2019, antara lain tidak diberikannya izin melanjutkan pendidikan bagi salah satu tenaga kependidikan dengan alasan yang tidak relevan. Tidak adanya tugas pokok dan fungsi yang jelas pada beberapa tenaga kependidikan di salah satu sub bagian, sehingga pada salah satu unit terdapat tenaga kependidikan yang lembur disaat rekan satu unitnya tidak diberikan pekerjaan. Analisa jabatan yang tidak transparan dan tidak akuntabel karna tidak berdasarkan golongan kepangkatan maupun kualifikasi pendidikan. Selisih pendapatan diluar gaji pokok yang bisa mencapai dua kali gaji pokok antar tenaga kependidikan di unit yang satu dengan unit yang lain. Permintaan pengadaan scanner untuk kebutuhan pekerjaan yang sudah diajukan tepat setahun yang lalu namun sampai penelitian ini diajukan belum terpenuhi meskipun diketahui adanya pengembalian anggaran berjumlah milyaran yang tidak dipergunakan di tahun anggaran 2018.

Oleh karena itu peneliti berkeinginan mengalanisa lebih lanjut bagaimana manajemen tenaga kependidikan Fakultas Ekonomi dan Bisnis USU dalam mendukung pencapaian Standar Nasional Pendidikan dari Renstra dan Renop FEB USU Tahun 2015-2019 sampai dengan implementasinya dengan tujuan sebagai masukan bagi para pengambil kebijakan di FEB USU.

Berdasarkan Restra FEB USU Tahun 20152019

1. Kualifikasi pendidikan, kompetensi, etos kerja, dan integritas tenaga kependidikan FEB USU masih rendah.

2. Pelatihan-pelatihan yang diberikan masih belum efektif meningkatkan kompetensi yang dibutuhkan.

3. Sebaran tenaga kependidikan juga tidak sesuai dengan kebutuhan yang berakibat kepada pelayanan yang tidak optimal.

4. Diperlukan pemetaan tenaga kependidikan yang meliputi kebutuhan, kompetensi, dan deskripsi kerja untuk membuat kebijakan yang tepat dalam rekrutmen dan sistem penghargaan.

Berdasarkan hasil observasi peneliti;

1. Tidak diberikannya izin melanjutkan pendidikan bagi salah satu tenaga kependidikan dengan alasan yang tidak relevan.

2. Tidak adanya tugas pokok dan fungsi yang jelas pada beberapa tenaga kependidikan.

3. Analisa jabatan yang tidak transparan dan tidak akuntabel karna tidak berdasarkan golongan kepangkatan maupun kualifikasi pendidikan. 
4. Selisih pendapatan diluar gaji pokok yang bisa mencapai dua kali gaji pokok antar tenaga kependidikan di unit yang satu dengan unit yang lain.

5. Permintaan pengadaan scanner untuk kebutuhan pekerjaan yang sudah diajukan tepat setahun yang lalu namun sampai penelitian ini diajukan belum terpenuhi meskipun diketahui adanya pengembalian anggaran berjumlah milyaran yang tidak dipergunakan di tahun anggaran 2018.

Rumusan masalah dalam penelitian ini adalah seberapa baik tingkat penilaian Manajemen Tenaga Kependidikan Fakultas Ekonomi dan Bisnis USU dalam Mendukung Pencapaian Standar Nasional Pendidikan berdasarkan Instrumen Akreditasi BAN PT, Akreditasi Institusi Perguruan Tinggi, Buku VI, Matriks Penilaian Borang dan Evaluasi-Diri, Tahun 2011.

\section{METODELOGI PENELITIAN}

Penelitian dilakukan di Fakultas Ekonomi dan Bisnis Universitas Sumatera Utara. Waktu penelitian dimulai dari Juli sampai dengan September 2019. Penelitian ini termasuk penelitian sensus karena menjadikan seluruh anggota populasi sebagai sampel.

Jenis penelitian ini bersifat deskriptif. Penelitian ini memberikan gambaran secara umum mengenai manajemen tenaga kependidikan di Fakultas Ekonomi dan Bisnis USU dalam mendukung pencapaian standar nasional pendidikan. Penelitian ini juga bersifat verifikasi (pengujian), yaitu untuk menguji seberapa jauh pencapaian/ implementasi dari Renstra dan Renop FEB USU Tahun 2015-2019 yang berhubungan dengan manajemen tenaga kependidikan.

\section{A. Instrumen Penelitian dan Skala Pengukuran}

1. Instrumen Penelitian
Dalam penelitian ini digunakan instrumen berupa daftar tabulasi penilaian berdasarkan Instrumen Akreditasi Perguruan Tinggi BANPT, Buku VI, Matrik Penilaian Borang dan Evaluasi Diri, Badan Akreditasi Nasional Perguruan Tinggi, Jakarta 2011, pada hal-hal yang berhubungan dengan manajemen tenaga kependidikan sebagai bahan wawancara (interview), observasi dan dokumentasi sebagai dasar pemberian penilaian.

\section{Skala Pengukuran}

Skala pengukuran yang digunakan dalam penelitian ini menyesuaikan dengan skala pengukuran yang digunakan pada instumen Akreditasi Institusi Perguruan Tinggi BAN-PT, Buku VI, Matriks Penilaian Borang dan Evaluasi Diri, Badan Akreditasi Nasional Perguruan Tinggi, Jakarta 2011, yaitu :

\section{Tabel 1. Skala Pengukuran}

\begin{tabular}{llc}
\hline \multicolumn{2}{c}{ Harkat dan Peringkat } \\
\hline 1 & Sangat Baik (SB) & 4 \\
\hline 2 & Baik (B) & 3 \\
\hline 3 & Cukup (C) & 2 \\
\hline 4 & Kurang (K) & 1 \\
\hline 5 & Sangat Kurang (SK) & 0 \\
\hline
\end{tabular}

\section{B. Indikator Variabel Penelitian}

Indikator variabel penelitian menggunakan poin-poin pada Instrumen Akreditasi Perguruan Tinggi BAN-PT, Buku VI, Matrik Penilaian Borang dan Evaluasi Diri, Badan Akreditasi Nasional Perguruan Tinggi, Jakarta 2011, pada poin-point yang berhubungan dengan manajemen tenaga kependidikan, yaitu sebagaimana tercantum pada tabel berikut ini;

\begin{tabular}{|c|c|c|}
\hline \multirow{3}{*}{ No } & \multicolumn{2}{|c|}{ Variabel Terikat } \\
\hline & \multicolumn{2}{|c|}{$\begin{array}{c}\text { Matrik Penilaian Borang dan Evaluasi Diri BAN-PT } \\
\text { yang Berhubungan dengan Manajemen Tenaga } \\
\text { Kependidikan }\end{array}$} \\
\hline & Elemen Penilaian & Indikator \\
\hline 1. & $\begin{array}{l}\text { Kejelasan, kerealistikan, } \\
\text { dan keterkaitan antar visi, } \\
\text { misi, tujuan dan sasaran } \\
\text { perguruan tinggi, dan } \\
\text { pemangku kepentingan } \\
\text { yang terlibat. }\end{array}$ & $\begin{array}{l}\text { Visi, misi, tujuan dan } \\
\text { sasaran yang: } \\
\text { (1) Sangat jelas. } \\
\text { (2) Sangat realistik. } \\
\text { (3) Saling terkait satu } \\
\text { sama lain. }\end{array}$ \\
\hline
\end{tabular}




\begin{tabular}{|c|c|c|}
\hline & & $\begin{array}{l}\text { (4) Melibatkan dosen, } \\
\text { mahasiswa, tenaga } \\
\text { kependidikan, alumni } \\
\text { dan masyarakat. }\end{array}$ \\
\hline 2. & $\begin{array}{l}\text { Sosialisasi visi dan misi } \\
\text { perguruan tinggi } \\
\text { dilaksanakan secara } \\
\text { sistematis dan berkelanjutan } \\
\text { kepada pemangku } \\
\text { kepentingan }\end{array}$ & $\begin{array}{l}\text { Visi dan misi perguruan } \\
\text { tinggi disosialisasikan } \\
\text { secara sistematis dan } \\
\text { berkelanjutan kepada } \\
\text { semua pemangku } \\
\text { kepentingan, internal } \\
\text { maupun eksternal. }\end{array}$ \\
\hline 3. & $\begin{array}{l}\text { Visi dan misi perguruan } \\
\text { tinggi dijadikan pedoman, } \\
\text { panduan, dan rambu-rambu } \\
\text { bagi semua pemangku } \\
\text { kepentingan internal serta } \\
\text { dijadikan acuan } \\
\text { pelaksanaan renstra, } \\
\text { keterwujudan visi, } \\
\text { keterlaksanaan misi, } \\
\text { ketercapaian tujuan melalui } \\
\text { strategi-strategi yang } \\
\text { dikembangkan. }\end{array}$ & $\begin{array}{l}\text { Visi dan misi dipahami } \\
\text { dengan baik dan dijadikan } \\
\text { acuan penjabaran renstra } \\
\text { pada semua tingkat unit } \\
\text { kerja. }\end{array}$ \\
\hline 4. & $\begin{array}{l}\text { Sistem pengelolaan } \\
\text { fungsional dan operasional } \\
\text { perguruan tinggi mencakup } \\
\text { fungsi pengelolaan } \\
\text { (planning, organizing, } \\
\text { staffing, leading, dan } \\
\text { controlling), yang } \\
\text { dilaksanakan secara efektif } \\
\text { untuk mewujudkan visi dan } \\
\text { melaksanakan misi } \\
\text { perguruan tinggi. }\end{array}$ & $\begin{array}{l}\text { Sistem pengelolaan } \\
\text { fungsional dan } \\
\text { operasional perguruan } \\
\text { tinggi mencakup semua } \\
\text { (lima) fungsi pengelolaan } \\
\text { yang dilaksanakan secara } \\
\text { efektif. }\end{array}$ \\
\hline 5. & $\begin{array}{l}\text { Perguruan tinggi memiliki } \\
\text { analisis jabatan, deskripsi } \\
\text { tugas, program peningkatan } \\
\text { kompetensi manajerial yang } \\
\text { menjamin terjadinya proses } \\
\text { pengelolaan yang efektif } \\
\text { dan efisien di setiap unit } \\
\text { kerja. }\end{array}$ & $\begin{array}{l}\text { Perguruan tinggi } \\
\text { memiliki: } \\
\text { (1) rancangan dan analisis } \\
\text { jabatan, } \\
\text { (2) uraian tugas, } \\
\text { (3) prosedur kerja, } \\
\text { (4) program peningkatan } \\
\text { kompetensi } \\
\text { manajerial yang } \\
\text { sistematis untuk } \\
\text { pengelola unit kerja, } \\
\text { yang menggambar- } \\
\text { kan keefektifan dan } \\
\text { efisiensi manajemen } \\
\text { operasi di setiap unit } \\
\text { kerja. }\end{array}$ \\
\hline 6. & $\begin{array}{l}\text { Keberadaan dan keefektifan } \\
\text { sistem audit internal, } \\
\text { dilengkapi dengan kriteria } \\
\text { dan instrumen penilaian } \\
\text { serta menggunakannya } \\
\text { untuk mengukur kinerja } \\
\text { setiap unit kerja, serta } \\
\text { diseminasi hasilnya. }\end{array}$ & $\begin{array}{l}\text { Perguruan tinggi memiliki } \\
\text { kriteria dan instrumen } \\
\text { penilaian, } \\
\text { menggunakannya untuk } \\
\text { mengukur kinerja setiap } \\
\text { unit, dan hasil } \\
\text { pengukurannya digunakan } \\
\text { serta didiseminasikan } \\
\text { dengan baik. }\end{array}$ \\
\hline 7. & $\begin{array}{l}\text { Sistem pengelolaan sumber } \\
\text { daya manusia yang lengkap, } \\
\text { transparan, dan akuntabel, } \\
\text { mencakup: perencanaan, } \\
\text { rekrutmen, seleksi, dan } \\
\text { pemberhentian pegawai, } \\
\text { orientasi dan penempatan } \\
\text { pegawai, pengembangan }\end{array}$ & $\begin{array}{l}\text { Dokumen formal sistem } \\
\text { pengelolaan sumber daya } \\
\text { manusia yang mencakup: } \\
\text { (1) perencanaan, } \\
\text { (2) rekrutmen, seleksi, } \\
\text { dan pemberhentian } \\
\text { pegawai } \\
\text { (3) orientasi dan }\end{array}$ \\
\hline
\end{tabular}

karir, remunerasi, penghargaan, dan sanksi.

penempatan pegawai,

(4) pengembangan karir,

(5) remunerasi, penghargaan, dan sanksi, yang transparan dan akuntabel berbasis pada meritokrasi.

\begin{tabular}{|c|c|}
\hline 8. & $\begin{array}{l}\text { Pedoman formal tentang } \\
\text { sistem monitoring dan } \\
\text { evaluasi, serta rekam jejak } \\
\text { kinerja dosen dan tenaga } \\
\text { kependidikan. }\end{array}$ \\
\hline 9. & $\begin{array}{l}\text { Pemetaan kebutuhan dan } \\
\text { ketersediaan tenaga } \\
\text { kependidikan }\end{array}$ \\
\hline 10. & $\begin{array}{l}\text { Upaya perguruan tinggi } \\
\text { dalam meningkatkan } \\
\text { kualifikasi dan kompetensi } \\
\text { tenaga kependidikan. }\end{array}$ \\
\hline & $\begin{array}{l}\text { Upaya antara lain dalam } \\
\text { bentuk: } \\
\text { (1) kesempatan belajar/ } \\
\text { pelatihan } \\
\text { (2) pemberian fasilitas } \\
\text { termasuk dana } \\
\text { (3) jenjang karir yang jelas } \\
\text { studi banding }\end{array}$ \\
\hline
\end{tabular}
Pedoman formal yang lengkap; dan ada bukti dilaksanakan secara konsisten. Jumlah cukup dan sangat baik kegiatannya.

Semua empat upaya berikut:

(1) kesempatan belajar/ pelatihan

(2) pemberian fasilitas termasuk dana

(3) jenjang karir yang jelas

(4) studi banding dilaksanakan dengan baik sehingga dapat meningkatkan kualifikasi dan kompetensi tenaga kependidikan. $\begin{array}{lll}\text { 11. } & \text { Instrumen survei kepuasan } \\ \text { dosen, pustakawan, laboran, } & \text { Instrumen untuk } & \text { mengukur kepuasan }\end{array}$ teknisi, dan tenaga administrasi terhadap sistem pengelolaan sumber daya manusia dosen, pustakawan, laboran, teknisi, dan tenaga administrasi, terhadap sistem pengelolaan sumber daya manusia, yang memiliki:

(1) validitas,

(2) reliabilitas, dan

(3) mudah digunakan

12. Pelaksanaan survei Hasil survei kepuasan kepuasan dosen, pustakawan, laboran, teknisi, tenaga administrasi, dan tenaga pendukung terhadap sistem pengelolaan sumber daya manusia. dosen, pustakawan, laboran, teknisi, dan tenaga administrasi terhadap sistem pengelolaan sumber-daya manusia yang:

(1) jelas,

(2) komprehensif,

(3) mudah diakses oleh pemangku kepentingan.

13. Pemanfaatan hasil survei kepuasan dosen, pustakawan, laboran, teknisi, dan tenaga administrasi terhadap sistem pengelolaan sumber daya manusia.

\section{Pemanfaatan hasil survei} dalam perbaikan yang berkelanjutan untuk mutu:

(1) pengelolaan sumber daya manusia,

(2) instrumen pengukuran kepuasan dosen, pustakawan, laboran, teknisi, tenaga administrasi, dan tenaga pendukung,

(3) analisis hasil survei kepuasan dosen, pustakawan, laboran, 


\begin{tabular}{|c|c|c|}
\hline & & $\begin{array}{l}\text { teknisi, tenaga } \\
\text { administrasi, dan } \\
\text { tenaga pendukung, }\end{array}$ \\
\hline 14. & $\begin{array}{l}\text { Penggunaan dana untuk } \\
\text { operasional (pendidikan, } \\
\text { penelitian, pengabdian pada } \\
\text { masyarakat, termasuk gaji } \\
\text { dan upah, dan investasi } \\
\text { prasarana, saran, dan SDM). } \\
\text { Jumlah dana operasional/ } \\
\left.\text { mahasiswa/tahun (=D } \text { D }_{\mathrm{OM}}\right) \\
\end{array}$ & $\begin{array}{l}\text { Jika } D_{\mathrm{OM}} \geq \mathrm{Rp} .18 \text { juta } \\
\text { maka skor }=4 .\end{array}$ \\
\hline 15. & $\begin{array}{l}\text { Sistem pengelolaan } \\
\text { prasarana dan sarana } \\
\text { berupa kebijakan, } \\
\text { peraturan, dan } \\
\text { pedoman/panduan untuk } \\
\text { aspek: } \\
\text { (1) Pengembangan dan } \\
\text { pencatatan, } \\
\text { (2) Penetapan penggunaan, } \\
\text { (3) Keamanan dan } \\
\text { keselamatan } \\
\text { penggunaan, } \\
\text { (4) Pemeliharaan/ } \\
\text { perbaikan/kebersihan. }\end{array}$ & $\begin{array}{l}\text { Dokumen pengelolaan } \\
\text { prasarana dan sarana } \\
\text { yang berisi kebijakan, } \\
\text { peraturan, dan } \\
\text { pedoman/panduan untuk } \\
\text { semua aspek berikut. } \\
\text { (1) Pengembangan dan } \\
\text { pencatatan } \\
\text { (2) Penetapan } \\
\text { penggunaan } \\
\text { (3) Keamanan dan } \\
\text { keselamatan } \\
\text { penggunaan } \\
\text { (4) Pemeliharaan/ } \\
\text { perbaikan/kebersihan } \\
\text { yang diimplementasi- } \\
\text { kan }\end{array}$ \\
\hline 16. & $\begin{array}{l}\text { Kecukupan dan mutu } \\
\text { prasarana yang dikelola } \\
\text { perguruan tinggi. } \\
\text { Ketersediaan: } \\
\text { (1) Prasarana akademik } \\
\quad \text { (kegiatan tridarma PT) } \\
\text { (2) Prasarana non-akademik } \\
\text { (fasilitas pengembangan } \\
\text { minat, bakat, dan } \\
\text { kesejahteraan) } \\
\end{array}$ & $\begin{array}{l}\text { Prasarana sangat lengkap, } \\
\text { dibuktikan dengan } \\
\text { tersedianya fasilitas } \\
\text { kegiatan akademik dan } \\
\text { non-akademik yang } \\
\text { sangat memadai. }\end{array}$ \\
\hline 17. & $\begin{array}{l}\text { Sistem informasi dan } \\
\text { fasilitas yang digunakan } \\
\text { perguruan tinggi dalam } \\
\text { administrasi (akademik dan } \\
\text { umum). }\end{array}$ & $\begin{array}{l}\text { Sistem informasi dan } \\
\text { fasilitas yang digunakan } \\
\text { perguruan tinggi dalam } \\
\text { administrasi yang } \\
\text { meliputi semua fasilitas } \\
\text { berikut. } \\
\text { (1) Komputer yang } \\
\text { terhubung dengan } \\
\text { jaringan luas/internet } \\
\text { (2) Software basis data } \\
\text { yang memadai. } \\
\text { (3) Akses terhadap data } \\
\text { yang relevan sangat } \\
\text { cepat. } \\
\end{array}$ \\
\hline 18. & $\begin{array}{l}\text { Sistem informasi untuk } \\
\text { pengelolaan prasarana dan } \\
\text { sarana yang transparan, } \\
\text { akurat dan cepat. }\end{array}$ & $\begin{array}{l}\text { Sistem informasi untuk } \\
\text { pengelolaan prasarana } \\
\text { dan sarana yang } \\
\text { transparan, akurat dan } \\
\text { cepat. }\end{array}$ \\
\hline
\end{tabular}

\begin{tabular}{|c|c|c|c|}
\hline \multirow[b]{2}{*}{ No } & \multicolumn{2}{|c|}{ Variabel Moderating } & Variabel Bebas \\
\hline & $\begin{array}{c}\text { Renstra dan Renop } \\
\text { FEB USU Tahun } \\
\text { 2015-2019 }\end{array}$ & Implementasi & $\begin{array}{c}\text { berdasarkan } \\
\text { dokumen, } \\
\text { observasi dan } \\
\text { wawancara }\end{array}$ \\
\hline
\end{tabular}

\begin{tabular}{ll}
\hline 1. \\
\hline 2. \\
\hline 3. \\
\hline 4. \\
\hline 5. \\
\hline 6. \\
\hline 7. \\
\hline 8. \\
\hline 9. \\
\hline 10. \\
\hline 11. \\
\hline 12. \\
\hline 13. \\
\hline 14. \\
\hline 15. \\
\hline 16. \\
\hline 17. \\
\hline 18. \\
\hline
\end{tabular}

\section{Teknik Pengumpulan Data}

Dalam penelitian ini penulis menggunakan observasi partisipan karena peneliti terlibat langsung dengan aktivitas orangorang yang sedang diamati karena peniliti adalah bagian dari tenaga kependidikan FEB USU.

Dalam penelitian ini juga penulis menggunakan wawancara bebas terpimpin yang hanya memuat pokok-pokok masalah yang diteliti selanjutnya dalam proses wawancara berlangsung mengikuti situasi pewawancara, apabila menyimpang dari pokok persoalan yang akan dibahas.

Teknik pengumpulan data yang terahir ialah teknik dokumentasi berdasarkan catatan, transkip, buku, photo, prasasti, notulen, agenda, dan sebagainya. Studi dokumen merupakan perlengkapan dari penggunaan metode observasi dan wawancara dalam penelitian kualitatif.

\section{Teknik Analisa Data}

Teknik analisa data dalam penelitian ini menggunakan analisis kualitatif. Hasil analisis yang diperoleh selanjutnya dikembangkan dengan pola hubungan tertentu. Langkahlangkah yang ditempuh penulis dalam menganalisa data adalah sebagai berikut:

1) Reduksi data

2) Penyajian data 
3) Verifikasi data

4) Penarikan kesimpulan

\section{E. Uji Keabsahan Data}

Uji keabsahan data pada penelitian ini menggunakan uji kredibilitas. Uji kredibilitas data atau kepercayaan terhadap data hasil penelitian terhadap berbagai macam cara, cara yang dilakukan untuk menguji keabsahan data dalam penelitian ini adalah menggunakan teknik triangulasi.

Pada penelitian ini, uji kredibilitas data hasil penelitian juga dilakukan dengan triangulasi teknik, yaitu menggunakan teknik pengumpulan data observasi, dokumentasi dan wawancara kepada subjek penelitian. Selain itu juga peneliti ini menggunakan triangulasi sumber yaitu dilakukan dengan cara mengecek data yang telah diperoleh melalui beberapa sumber yaitu dokumen, tenaga kependidikan struktural dan tenaga kependidikan non struktural.

\section{PEMBAHASAN}

\section{A. Deskripsi Hasil Penelitian}

Berdasarkan hasil pengumpulan data, kuesioner, observasi, dan wawancara, ditemukan hasil sebagai berikut;

1) Visi misi, tujuan dan sasaran, serta pemangku kepentingan yang terlibat, khususnya tenaga kependidikan dianggap sudah cukup jelas, realistik dan saling beterkaitan satu dengan yang lainnya. Sehingga layak mendapatkan penilaian maksimal, sangat baik, yaitu 4 poin.

2) Berdasarkan Renstra FEB USU 2015-2019, telah dicantumkan penguatan visi dan komitmen pada bagian strategi pengembangan pada nomor urut satu. Begitu juga pada bagian program kerja, membangun komitmen sivitas akademika dan tenaga kependidikan
USU berada pada nomor urut satu. Pada tabel program kerja Rensta FEB USU halaman 39, disebutkan bahwa kebijakan yang akan dilakukan adalah pemangku kepentingan memberikan teladan dan dukungan penuh serta berpartisipasi secara optimal untuk mewujudkan visi dan melaksanakan misi FEB USU dengan menegakkan peraturan secara konsisten. Sedangkan kegiatan yang dilakukan salah satunya adalah melakukan sosialisasi dan evaluasi Renstra secara sistematis dan berkelanjutan bersama semua pemangku kepentingan melalui diskusi, FGD, pemasangan baliho, dan penyebaran brosur, yang akan dilakukan setiap tahunnya.

Berdasarkan Renop FEB USU tahun 20152019 dicantumkan pada target dan indikator kinerja utama, sasaran 1, program pokok salah satunya adalah meningkatkan partisipasi sivitas akademika secara optimal untuk mewujudkan visi dan melaksanakan misi FEB USU dengan menegakkan peraturan secara konsisten, dengan kegiatan membuat Renstra pada setiap satuan kerja (program studi/departemen) yang sinkron dengan Renstra FEB USU, serta melakukan sosialisasi dan evaluasi Renstra secara sistematis dan berkelanjutan bersama semua pemangku kepentingan melalui diskusi, FGD, pemasangan baliho, dan penyebaran brosur. Target pada kegiatan sosialisasi/ pertemuan adalah sebanyak 14 kegiatan per tahun.

Berdasarkan kebijakan yang tertuang pada renstra FEB USU 2015-2019 sehubungan dengan sosialisai visi dan misi, maka FEB USU layak diberikan penilaian baik, 3 poin.

Selanjutnya, berdasarkan hasil observasi dan wawancara dengan sebagian tenaga kependidikan tentang implementasi kebijakan diketahui bahwa sosialisasi visi dan misi dalam bentuk seminar yang diperuntukkan kepada seluruh civitas akademika FEB USU termasuk tenaga kependidikan pernah diadakan saat periode kepemimpinan yang 
sebelumnya. Namun sejak periode kepemimpinan saat ini belum pernah lagi diadakan khususnya yang mengikutsertakan tenaga kependidikan. Penyampaian visi dan misi memang sering dilakukan pada setiap kegiatan atau acara-acara resmi fakultas. Isi visi dan misi juga dibuat pada salah satu bagian dinding kantor utama administrasi, banner-banner, situs-situs yang berkaitan, buku-buku peraturan, tulisan-tulisan maupun karya-karya ilmiah yang berkaitan. Namun sosialisasi visi dan misi tersebut belum dilaksanakan secara sistematis dan belum berkelanjutan antara lain karena FEB USU tidak memiliki kegiatan khusus sosialisasi yang terjadwal yang mengikut sertakan tenaga kependidikan sebagai salah satu bagian dari FEB USU. Sehingga, berdasarkan implementasi kebijakan yang berhubungan dengan tenaga kependidikan, maka FEB USU hanya layak mendapatkan penilaian kurang, yaitu 1 poin.

Menurut Charlotte Buhler, Sosialisasi adalah suatu proses yang membantu anggota masyarakat untuk belajar dan menyesuaikan diri terhadap bagaimana cara hidup dan bagaimana cara berpikir kelompoknya, agar ia dapat berperan dan berfungsi dalam kelompok tersebut. Sedangkan manfaat visi adalah 1 . Menumbuhkan standar kerja yang prima. Karena apabila seorang karyawan memahami bahwa dia bekerja untuk suatu tujuan yang sangat mulia, maka dia akan bekerja penuh semangat dan meletakkan standar prima untuk setiap pekerjaannya, 2. Menumbuhkan rasa kebermaknaan. Karena salah satu tempat untuk karyawan dalam mencari makna kehidupan adalah lingkungan pekerjaannya, 3 . Menumbuhkan komitmen dan semangat kerja karyawan. Karena karyawan tidak akan bekerja dengan penuh antusias apabila dia tidak mengetahui untuk apa dia bekerja. Namun, jika dia mengetahui apa saja kontribusi perusahaan kepada masyarakat dia akan termotivasi bahwa dia bekerja tidak hanya untuk perusahaan, tetapi juga untuk masyarakat.

Berdasarkan pengertian sosialisasi dan manfaat visi tersebut, maka peneliti menyimpulkan bahwa sosialisasi visi dan misi khususnya pada tenaga kependidikan dianggap belum berhasil karena pola pikir serta peran dan fungsi tenaga kependidikan dalam mewujudkan visi dan misi fakultas masih belum sejalan, antara lain terlihat dengan belum terciptanya standar kerja yang prima, masih rendahnya rasa kebermaknaan, serta rendahnya komitmen dan semangat kerja pada sebagian besar tenaga kependidikan di lingkungan FEB USU.

Berdasarkan arah kebijakan dan implementasinya, maka penilaian pada Matrik Penilaian Borang dan Evaluasi Diri BAN PT dalam hal sosialisasi visi dan misi yang sistematis dan berkelanjutan khususnya tenaga kependidikan, FEB USU hanya layak mendapatkan penilaian kurang, yaitu 1 poin.

3) Berdasarkan kebijakan yang tertuang pada Renstra FEB USU Tahun 2015-2019, visi dan misi Fakultas Ekonomi dan Bisnis USU relatif sudah dijadikan sebagai pedoman, panduan, dan rambu-rambu bagi semua kepentingan internal serta dijadikan sebagai acuan pelaksanaan renstra, keterwujudan visi, keterlaksanaan misi, ketercapaian tujuan melalui strategi-strategi yang dikembangkan. Salah satunya dengan dicantumkannya kegiatan membuat Renstra pada setiap satuan kerja (program studi/departemen) yang sinkron dengan Renstra FEB USU, pada tabel program kerja Renstra FEB USU 2015-2019 halaman 39.

Namun pada renstra tersebut kurang jelas menjabarkan langkah-langkah bagaimana mewujudkan visi sebagai fakultas yang terkemuka yang dikenal unggul dan memenuhi kebutuhan pasar dalam persaingan 
global pada tahun 2020 dalam kaitannya dengan tenaga kependidikan. Karena terkemuka dan unggul menurut peneliti selayaknya menggunakan perbadingan prestasi/ keberhasilan yang sudah diraih FEB USU saat ini dengan prestasi/ keberhasilan Fakultas Ekonomi dan Bisnis di perguruan tinggi lainnya di di Sumatera atau di Indonesia. Jika mengkaitkan dengan tugas pokok dan fungsi tenaga kependidikan, maka diperlukan adanya rencana dan strategi berupa upaya menjadikan layanan administrasi pendidikan di FEB USU menjadi rujukan layanan administrasi pendidikan di Sumatera atau di Indonesia. Langkah-langkah bisa yang ditempuh antara lain dengan melakukan banyak modernisasi pelayanan administrasi demi efektifitas dan efisiensi. Aktif dalam kegiatan perlombaan layanan administrasi seperti tenaga administrasi akademik berprestasi, tenaga arsiparis berprestasi, laboran berprestasi, dan lain-lain sebagainya yang bisa menunjukkan ke publik bahwa layanan administrasi pendidikan di USU terbaik di Sumatera atau di Indonesia.

Peneliti menilai adanya kesalahan paradigma memahami status unggul dan terkemuka di mayoritas civitas akademika FEB USU. Karena unggul dan terkemuka bukan dinilai dari status PTN dan bukan pula karena usia yang sudah puluhan tahun.

Pada renstra FEB USU juga tidak mencantumkan rencana dan strategis pada level sub bagian yang menjadi naungan tenaga kependidikan secara struktur formal, sehingga tidak ada rencana strategi maupun indikator atau tolak ukur pencapaian yang bisa dievaluasi sub bagian beserta tenaga kependidikan di bawah naungannya sebagai patokan keterwujudan dan pencapaian visi dan misi Fakultas secara berkala.

Berdasarkan Renop FEB USU tahun 20152019, telah dicantumkan antara lain sasaran untuk menajadikan tenaga kependidikan berkemampuan dan berketerampilan tinggi, melakukan sosialisasi dan evaluasi Renstra secara sistematis dan berkelanjutan dengan indikator 14 kegiatan per tahun, melakukan evaluasi tentang kualitas pelayanan dengan indikator terlaksananya survey kepuasan layanan, mendorong tenaga kependidikan untuk meningkatkan jenjang pendidikan ke S1 dengan indikator penambahan 1 orang per tahunnya.

Maka, berdasarkan arah kebijakan yang tertuang dalam Renstra dan Renop FEB USU Tahun 2015-2019 tentang menjadikan visi misi sebagai pedoman, panduan, dan ramburambu bagi semua pemangku kepentingan internal serta dijadikan acuan pelaksanaan renstra, keterwujudan visi, keterlaksanaan misi, ketercapaian tujuan melalui strategistrategi yang dikembangkan, khususnya yang berhubungan dengan tenaga kependidikan, maka FEB USU layak mendapatkan penilai cukup, 2 poin.

Berdasarkan hasil observasi dan wawancara mengenai implementasi kebijakannya pada Renstra dan Renop FEB USU Tahun 20152019 tersebut diketahui bahwa penyusunan Renstra dan Renop FEB USU hanya melibatkan pejabat struktural tenaga kependidikan dan tidak menampung aspirasi tenaga kependidikan secara keseluruhan. Tidak adanya kegiatan sosialisasi dan evaluasi terhadap Renstra dan Renop khususnya yang berhubungan yang dengan tenaga kependidikan, sehingga jauh dari penilaian sistematis dan berkelanjutan. Tidak terlaksananya survey kepuasan terhadap pelayanan tenaga kependidikan. Tidak adanya pelatihan peningkatan mutu pelayanan. Tidak adanya upaya mendorong tenaga kependidikan untuk meningkatkan jenjang pendidikan ke S1, malahan menolak permohonan izin melanjutkan pendidikan tenaga kependidikan yang dibiayai secara mandiri. Sehingga implementasi kebijakan 
Renstra dan Renop tersebut hanya layak mendapatkan penilaian kurang, yaitu 1 poin.

4) Sebagai lembaga pendidikan tinggi negeri FEB USU sudah memiliki sistem pengelolaan fungsional dan operasional yang berpedoman pada aturan-aturan pemerintah. Berdasarkan Renstra dan Renop FEB USU Tahun 20152019 juga sudah disebutkan bahwa FEB USU akan menyempurnakan tata pamong dan sistem penjaminan mutu, dengan kebijakan melaksanakan Good University Governance, menyusun, menyesuaikan dan menjalankan Standard Operating Procedure (SOP), dengan kegiatan 1. mengembangkan sistem pengelolaan fungsional dan operasional fakultas yang efektif dan efisien dan 2 . melakukan analisis dan evaluasi jabatan untuk membuat deskripsi jabatan sehingga menempatkan the right man on the right place. (Renstra FEB USU hal 39). Sehingga, berdasarkan arah kebijakan, FEB USU layak mendapatkan penilaian baik, 3 poin dalam keberadaan sistem pengelolaan fungsional dan operasional perguruan tinggi khususnya yang berhubungan dengan tenaga kependidikan.

Berdasarkan hasil observasi dan wawancara mengenai implementasi kebijakan tersebut, FEB USU belum tegas menjadikan pemenuhan standar nasional pendidikan sebagai pedoman sistem pengelolaan fungsional dan operasional serta pencapaian visi dan misi FEB USU, antara lain dapat dilihat dari tidak adanya upaya menjadikan pengisian borang akreditasi perguruan tinggi sebagai acuan pekerjaan secara berkala. Sebagai contoh, masih minimnya sistem pelaporan berkala persentase kelulusan mahasiswa, persentase mahasiswa yang sudah seminar proposal, persentase mahasiswa yang sudah sidang skripsi, persentase kelulusan mahasiswa dalam satu mata kuliah, dan datadata lain sebagainya yang bisa dijadikan sebagai acuan pengambilan kebijakan fungsional dan operasional oleh para pengambil kebijakan sebagai bahan evaluasi terhadap proses pendidikan secara berkala. Data-data tersebut hanya dianggap diperlukan saat menjelang penilaian akreditasi.

Contoh lain adalah minimnya pelatihan sesuai dengan kebutuhan maupun studi banding dalam upaya peningkatan kualitas dan kompetensi tenaga kependidikan khususnya tenaga kependidikan administrasi akademik.

Tingkat penggunaan dan pemahaman aplikasi microsoft office tenaga kependidikan bidang akademik yang tergolong rendah terkesan diabaikan oleh pengambil kebijakan FEB USU. Sehingga masih dapat ditemukan tenaga kependidikan akademik yang membuat suratsurat administrasi mahasiswa seperti surat undangan seminar, surat undangan skripsi, surat permohonan pengajuan PKA dan lain sebagainya dengan hanya menggunakan sistem copy paste dengan microsoft word, sehingga sangat sulit untuk tabulasi/ rekapitulasi dan pelaporannya dan rentan terjadi salah pengetikan data.

Tenaga kependidikan yang ditugaskan untuk mengikuti pelatihan aplikasi Sistem Informasi Akademik (SIA) tidak semua dimaksimalkan fungsinya dalam menginput kurikulum dan nilai akademik, maupun saat evaluasi akademik. Sebagian tenaga administrasi yang ditugaskan melakukan evaluasi akademik tidak memiliki akses SIA sehingga relatif sulit mendapatkan data yang akurat untuk dievaluasi. Hal tersebut tidak sesuai dengan prinsip efektif dan efisien dalam pekerjaan.

Hal-hal tersebut di atas terjadi antara lain karena kurangnya komitmen dan pemahaman pengambil kebijakan serta tenaga kependidikan terhadapat pencapaian visi, misi dan renstra FEB USU. Oleh karena itu, maka penilaian implementasi sistem pengelolaan fungsional dan operasional dalam mewujudan visi dan misi khususnya yang berhubungan dengan tenaga kependidikan, FEB USU hanya 
layak mendapatkan penilaian kurang, yaitu 1 poin.

5) Berdasarkan hasil observasi dan wawancara mengenai arah kebijakan sehubungan dengan sistem analisis jabatan dan program peningkatan kompetensi manajerial yang dimiliki FEB USU sudah layak mendapatkan penilaian baik, yaitu 3 poin. Hal tersebut dikarenakan sebagai lembaga pendidikan tinggi negeri FEB USU sudah memiliki sistem analisis jabatan, program peningkatan kompetensi manajerial yang berpedoman pada aturan-aturan pemerintah. Berdasarkan Renstra dan Renop FEB USU Tahun 20152019 juga sudah dicantumkan target dan indikator utama dengan program pokok menyempurnakan tata pamong dan sistem penjaminan mutu dengan kegiatan antara lain menyusun Standar Operating Procedure (SOP) dalam pelaksanaan tata kelola Fakultas/ Departemen/Program studi, dengan target penambahan 5 SOP setiap tahunnya dihitung dari 15 SOP pada tahun 2016 sampai dengan 35 SOP pada tahun 2019. Selanjutnya ialah dengan kegiatan melakukan analisis dan evaluasi jabatan untuk membuat deskripsi jabatan sehingga menempatkan the right man on the right place. Kegiatan selanjutnya adalah melibatkan seluruh satuan kerja terkecil dalam menyusun Rencana Bisnis Anggaran. (Renop FEB USU Tahun 20152019 halaman 7)

Berdasarkan hasil observasi dan wawancara mengenai implementasi, FEB USU dinilai kurang dalam transparansi, akuntabilitas, meritokrasi dan prinsip keadilan. Sebagai contoh kasus, seorang tenaga kependidikan golongan III lulusan S2 Akuntansi Fakultas Ekonomi USU (ijazah belum dicantumkan dalam kepangkatan) digantikan posisinya di bagian keuangan dengan seorang tenaga kependidikan golongan II dengan ijazah S1 Ekonomi dari universitas swasta (ijazah belum disesuaikan dengan kepangkatan). Atau contoh lain seorang tenaga kependidikan dengan status pegawai tetap non PNS menjadi koordinator lapangan pelaksanaan kegiatan ujian penerimaan mahasiswa dan mengabaikan keberadaan pegawai dengan status PNS golongan III lainnya. Contoh lain ialah peneliti yang pernah ditugaskan Biro Rektorat USU sebagai peserta diklat kearsipan di Pusdiklat ANRI Bogor selama satu bulan penuh, namun tidak diperkenankan mengaplikasikan ilmunya dan tidak juga ditempatkan di bagian yang berhubungan langsung dengan kearsipan Fakultas.

Deskripsi tugas dan prosedur kerja setiap unit di Fakultas Ekonomi dan Bisnis USU masih dinilai kurang menjamin proses pengelolaan yang efektif dan efisien. Sebagai contoh, pada bagian akademik, mahasiswa yang kehilangan KRS dan KHS diharuskan membuat permohonan keterangan aktif kuliah yang ditandatangani di atas materai 6000 . Selanjutnya surat keterangan aktif kuliah yang sudah ditandatangani oleh Wakil Dekan I akan dibawa mahasiswa untuk pengurusan Surat Keterangan Hilang dari pihak Kepolisian. Surat Keterangan Hilang dari kepolisian adalah persyaratan permintaan print out KRS dan KHS pengganti di bagian akademik. Selanjutnya, yang terakhir, KRS dan KHS pengganti tersebut diserahkan lagi ke petugas administrasi lainnya yang juga masih di bagian akademik untuk pembuatan surat permohonan penandatanganan KRS dan KHS pengganti tersebut ke Ketua Prodi.

Prosedur kerja tersebut di atas sangatlah panjang dan sangat berbelit-belit dikarenakan seluruh fakultas di lingkungan Universitas Sumatera Utara sudah memiliki Sistem Informasi Akademik yang antara lain berisi KRS dan KHS yang berasal dari database yang sama dari yang di keluarkan oleh bagian akademik. Sehingga sudah sangat memungkinkan prosedur kerja sehubungan 
dengan kehilangan KRS dan KHS mahasiswa tersebut dipangkas agar tidak berbelit-belit dan menyusahkan mahasiswa sekaligus menambah beban kerja tenaga kependidikan. Bahkan, dalam waktu sesegera mungkin, kegiatan administrasi seharusnya sudah bisa menerapkan prinsip paperless.

Pada program peningkatan kompetensi manajerial, khususnya yang berhubungan dengan tenaga kependidikan, FEB USU masih terkesan pasif karena hanya mengikuti program kegiatan yang berasal dari biro rektorat USU tanpa ada analisa kebutuhan dan perencanaan sendiri. Minim usulan-usulan sehubungan dengan kebutuhan peningkatan kompetensi manajerial tenaga kependidikan yang berasal dari FEB USU sendiri. Adapun pengiriman tenaga kependidikan atas biaya fakultas untuk kepentingan peningkatan manajerial sebagaimana yang diketahui peneliti adalah pengiriman dua orang tenaga kependidikan bersama dengan Wakil Dekan II untuk mengikuti kegiatan pelatihan sehubungan dengan kegiatan pengadaan barang dan jasa di Bali. Namun yang menjadi keganjilan adalah tenaga kependidikan yang diikutsertakan adalah Kasubbag Umum dan Perlengkapan yang akan memasuki masa pensiun beberapa bulan setelahnya dan satu orang staf akademik dari Prodi yang secara struktural dan tupoksi tidak berhubungan dengan kegiatan pengadaan barang dan jasa.

Berdasarkan hal-hal tersebut di atas, maka penilaian implementasi sistem analisis jabatan, deskripsi tugas, program peningkatan kompetensi manajerial dan prosedur kerja yang menjamin terjadinya proses pengelolaan yang efektif dan efisien FEB USU hanya layak mendapatkan penilaian kurang, yaitu 1 poin.

6) Berdasarkan hasil observasi dan wawancara mengenai kebijakan tertulis, FEB USU diketahui tidak memiliki kebijakan sistem audit internal untuk mengukur kinerja pada unit kerja yang berhubungan langsung dengan tenaga kependidikan yaitu unit kerja sub bagian. Hal tersebut dikarenakan FEB USU berdasarkan Renstra dan Renop FEB USU Tahun 2015-2019 hanya menggolongkan program studi sebagai unit kerja di bawah fakultas. Sedangkan sub bagian tidak digolongkan sebagai unit kerja sehingga tidak memiliki indikator pencapaian/ keberhasilan kinerjanya. Oleh karena itu, berdasarkan arah kebijakan FEB USU hanya layak mendapatkan penilaian sangat kurang, yaitu 0 poin. Namun berdasarkan hasil observasi dan wawancara diketahui bahwa FEB USU secara tidak langsung memiliki metode untuk mengaudit secara internal kinerja setiap unit kerja dengan patokan kesiapan unit kerja dalam penyelesaian pekerjaan tepat waktu pekerjaan-pekerjaan yang diarahkan oleh Biro Rektorat USU. Namun hasilnya tidak didesiminasi secara efektif dengan ketercapaian visi dan misi. Sehingga berdasarkan penilaian implementasi kebijakan audit internal FEB USU hanya layak mendapatkan penilaian kurang, yaitu 1 poin.

7) Berdasarkan hasil observasi dan wawancara mengenai arah kebijakan, FEB USU sebagai lembaga pendidikan tinggi negeri sudah memiliki sistem pengelolaan sumber daya manusia yang lengkap mencakup perencanaan, rekrutmen, seleksi, dan pemberhentian pegawai, pengembangan karir, remunerasi, penghargaan, dan sanksi sehingga layak mendapatkan penilaian baik, 3 poin. Namun implementasinya masih dinilai kurang.

Implementasi kebijakan penyusunan perencanaan yang sejalan dengan pemenuhan visi, misi, renstra dan renop FEB USU juga masih dinilai kurang. Sebagai contoh, sampai saat ini belum ada satu orangpun tenaga laboran meskipun sudah ada beberapa 
laboratorium yang sudah digunakan dalam menunjang kegiatan pendidikan. Contoh lain ialah dengan masih adanya pembiaran tenaga kependidikan administrasi akademik yang hanya memiliki tingkat pendidikan SMP yang tidak sesuai dengan Permenristek Dikti Nomor 44 Tahun 2015 Pasal 30 yang menyatakan bahwa tenaga administrasi memiliki kualifikasi paling rendah SMA atau sederajat.

Selain 52 tenaga kependidikan sebagaimana daftar di atas, ada beberapa alumni/ mahasiswa di luar waktu magang yang dipekerjakan di ruang sekretaris dekan maupun di beberapa prodi yang tugas pokok dan fungsinya sebagaimana halnya tugas pokok dan fungsi tenaga kependidikan. Bahkan di beberapa prodi tugas pokok dan fungsi alumni/ mahasiswa tersebut tergolong lebih penting daripada tugas pokok dan fungsi tenaga kependidikan yang berstatus PNS maupun pegawai tetap non PNS yang juga bekerja pada prodi yang sama. Hal ini mengindikasikan beberapa hal antara lain; 1 . Kurangnya analisa beban kerja, analisa kebutuhan tenaga kependidikan, dan pemetaan tenaga kependidikan, 2. Rendahnya tingkat kepercayaan pengambil kebijakan terhadap kualitas pekerjaan tenaga kependidikan dengan status PNS maupun tenaga tetap Non PNS, 3. Kurangnya pembinaan dan peningkatan mutu, kualitas dan kompetensi tenaga kependidikan.

Berdasarkan data kepegawaian juga di ketahui bahwa terdapat 13 tenaga kependidikan yang memiliki ijazah yang lebih tinggi dari ijazah yang diakui dalam status kepegawaiannya, karena beberapa alasan yang merupakan kebijakan internal USU namun tidak sesuai dengan kebijakan lembaga pendidikan tinggi sebagaimana mestinya.

Sistem rekrutmen dan seleksi tenaga kependidikan dengan status PNS dan tenaga tetap non PNS FEB USU mengikuti sistem rekrutmen yang berasal dari biro rektorat USU, namun untuk tenaga honorer atau tenaga harian lepas per kegiatan, FEB USU tidak memenuhi prinsip transparansi karena sistem rekrutmen tidak terbuka untuk umum. Tenaga honorer yang bekerja di FEB USU umumnya berasal dari rekomendasi pihakpihak tertentu.

Penerapan disiplin sampai dengan pemberhentian pegawai FEB USU belum berjalan maksimal karena belum berhasil memberhentikan tenaga kependidikan yang sudah berbulan-bulan tidak masuk kerja tanpa alasan yang sah.

Sebagai contoh dalam hal transparansi, akuntabel, maupun meritokrasi. Tidak ada penilaian yang jelas tentang orientasi penempatan tenaga kependidikan. Sebagai contoh, seorang tenaga kependidikan yang pernah dikirim mengikuti diklat kearsipan di pusdiklat ANRI selama 1 bulan dan telah pula mendapat surat penugasan pembenahan kearsipan dari Rektor USU namun tidak diperkenankan melakukan kegiatan pembenahan kearsipan, dan dipindahkan ke bagian akademik.

Contoh lain, seorang tenaga kependidikan yang sudah memiliki banyak pelatihan, pengetahuan dan pengalaman mengenai pengadaan barang dan jasa namun dipindahtugaskan pada bagian akademik, meskipun sesekali pendapatnya tetap juga diminta sebagai rujukan dalam pengambilan keputusan sehubungan dengan kegiatan pengadaan barang dan jasa.

Remunerasi tenaga kependidikan pada dasarnya sudah relatif cukup bagi tenaga kependidikan di lingkungan Fakultas Ekonomi dan Bisnis USU. Namun yang sering menjadi permasalahan adalah pembagiannya, transparansi, akuntabilitas dan juga konsistensi dalam pemilihan siapa yang berhak mendapatkan remunerasi tersebut. Sebagai contoh, saat ada kegiatan yang 
diselenggarakan oleh bagian akademik, tidak semua tenaga kependidikan di bagian akademik dimasukkan pada kepanitiaan kegiatan, sedangkan sebaliknya, tenaga kependidikan pada bagian keuangan seluruhnya hampir selalu dimasukkan di setiap kepanitiaan kegiatan.

Sistem pemberian penghargaan relatif tidak berjalan. Sebagai salah satu contoh, berdasarkan hasil wawancara dengan salah satu tenaga kependidikan, pihak pengambil kebijakan hanya bersedia menyertakan tenaga kependidikan yang pilihannya untuk mengikuti pemilihan tenaga kependidikan berprestasi, dan tidak menerima usulan lainnya meskipun ada usulan dari kepala sub bagian. Hal ini memicu sikap apatis sebagian tenaga kependidikan untuk bekerja lebih giat.

Kebijakan Pengembangan karir FEB USU masih relatif kurang transparan, kurang akuntabel dan kurang menerapkan prinsip meritokrasi. Sebagai contoh seorang tenaga kependidikan yang memiliki ijazah S2 Fakultas Ekonomi dan Bisnis USU dihambat dalam pengusulan pencantuman ijazahnya.

Berdasarkan hal-hal tersebut di atas, maka penilaian implementasi sistem pengelolaan sumber daya manusia FEB USU hanya layak mendapatkan penilaian kurang, yaitu 1 poin.

Berdasarkan hasil survey tingkat kepuasan terhadap seluruh (52 orang) tenaga kependidikan, hanya 42 tenaga kependidikan memberi jawaban, dan terhadap sistem pengelolaan SDM tenaga kependidikan FEB USU yang menjawab sangat baik/ baik dalam hal perencanaan sebanyak 16 orang $(52 \%)$, dalam hal sistem rekrutmen dan seleksi sebanyak 16 orang (38\%), dalam hal orientasi dan penempatan sebanyak 17 orang (40\%), dalam hal penghargaan dan remunerasi sebanyak 9 orang (21\%), dalam hal pemberian sanksi dan pemberhentian sebanyak 10 orang (24\%), dalam hal transparansi sebanyak 9 orang (21\%), dalam hal akuntabilitas sebanyak 13 orang (33\%), dalam hal meritokrasi sebanyak 16 orang (38\%), dalam hal prinsip keadilan sebanyak 6 orang (14\%), dalam hal kesejahteraan sebanyak 13 orang $(31 \%)$.

8) Berdasarkan hasil observasi dan wawancara mengenai arah kebijakan tertulis, sebagai lembaga pendidikan di bawah naungan pemerintah, maka antara lain berlaku Peraturan Kepala Badan Kepegawaian Negara Nomor 21 Tahun 2010 Tentang Ketentuan Pelaksanaan Peraturan Pemerintah Nomor 53 Tahun 2010 Tentang Disiplin Pegawai Negeri Sipil, dan peraturan-peraturan lainnya yang berlaku di lingkungan USU dan Fakultas. Sasaran Kerja Pegawai (SKP) adalah salah satu bentuk formal sistem monitoring, evaluasi serta rekam jejak kinerja tenaga kependidikan di lingkungan FEB USU, sehingga secara keseluruhan dalam hal arah kebijakan FEB USU layak mendapatkan penilaian baik, 3 poin. Namun dalam implementasinya, baik peraturan disiplin maupun penilaian kinerja tenaga kependidikan masih relatif jauh dari kata konsisten dalam penerapan maupun akurat dalam penilaian. Sebagai contoh, ada beberapa tenaga kependidikan yang tidak masuk kerja berturut-turut selama lebih dari 3 bulan tanpa alasan yang sah tidak dilakukan pemberhentian. Berdasarkan hasil wawancara dengan Kasubbag SDM dan salah satu stafnya ditegaskan juga bahwa penilaian SKP tenaga kependidikan tidak akurat menggambarkan penilaian yang sesungguhnya. Sehingga sulit untuk melakukan monitoring, evaluasi serta rekam jejak kinerja tenaga kependidikan berdasarkan isi SKP. Sehingga, berdasarkan penilaian implementasi kebijakan, FEB USU hanya layak mendapatkan penilaian kurang, yaitu 1 poin. 
9) Pada Renstra FEB USU Tahun 2015-2019 telah disebutkan bahwa kualifikasi pendidikan, kompetensi, etos kerja, dan integritas tenaga kependidikan masih rendah. Di samping itu, sebaran tenaga kependidikan tidak sesuai dengan kebutuhan yang berakibat kepada pelayanan yang tidak optimal. Dalam upaya peningkatan kualikasi dan kompetensi tenaga kependidikan agar dapat mendukung peningkatan jumlah dan mutu pelayanan, USU memberikan kesempatan belajar/pelatihan kepada tenaga kependidikan. Hanya saja pelatihan-pelatihan yang diberikan masih belum efektif untuk dapat meningkatkan kompetensi yang dibutuhkan untuk mendukung proses belajar mengajar. Oleh sebab itu, diperlukan pemetaan tenaga kependidikan meliputi kebutuhan, kompetensi, dan deskripsi kerja untuk membuat kebijakan yang tepat dalam rekrutmen dan sistem penghargaan (Renstra FEB USU Tahun 2015-2019, halaman 27)

Berdasarkan tabel program kerja pada Renstra FEB USU Tahun 2015-2019 juga telah disebutkan bahwa Program Studi akan mempersiapkan SDM USU yang bermutu dengan melakukan kebijakan revitalisasi dan kaderisasi SDM yang kegiatannya antara lain dengan memenuhi proporsi ideal kecukupan tenaga pendidik dan kependidikan serta menyiapkan teknisi, analis, dan laboran yang kompeten (Renstra FEB USU Tahun 20152019, halaman 44).

Secara arah kebijakan, maka FEB USU layak mendapatkan penilaian baik, 3 poin dalam hal pemetaan kebutuhan dan ketersediaan tenaga kependidikan.

Namun, berdasarkan hasil observasi dan wawancara dengan kasubbag SDM dan salah satu stafnya diketahui bahwa FEB USU belum melakukan pemetaan sebaran tenaga kependidikan secara khusus, spesifik dan akurat sebagai dasar analisa kebutuhan tenaga kependidikan, perencanaan dan dasar pengambilan kebijakan ke depannya. Kualitas tenaga kependidikan juga relatif masih rendah, tidak merata, sangat minimnya kegiatan peningkatan kualitas, kualifikasi dan kompetensi. Minimnya upaya efektifitas dan efisiensi pekerjaan, kurang koordinasi dan kerjasama, lambat dalam mengantisipasi kemajuan teknologi dalam bidang administrasi. Dan hal tersebut diperburuk dengan adapanya penerapan prinsip efisiensi anggaran oleh para pengambil kebijakan yang sangat merugikan perkembangan institusi.

Beberapa contoh antara lain, adanya seorang tenaga kependidikan yang diberikan banyak beban tanggung jawab atas dasar kepercayaan, kedekakan dan keberadaan honor kegiatan sedangkan tenaga kependidikan yang lain yang berada pada unit yang sama yang sebenarnya secara kualifikasi dan pendidikan juga memiliki kemampuan yang sama tidak diberikan beban dan tanggung jawab yang cukup. Contoh lain adalah penugasan tenaga kependidikan yang berjenis kelamin laki-laki seorang diri di ruang sekretaris dekan meskipun ada beberapa tenaga kependidikan lainnya ditugaskan di unit lainnya dengan nyaris tanpa beban pekerjaan karena lebih sering terlihat hanya duduk-duduk di kursinya tanpa adanya aktifitas berarti.

Sehingga, berdasarkan penilaian implementasi kebijakan dalam hal pemetaan kebutuhan dan ketersediaan tenaga kependidikan, FEB USU hanya layak mendapat penilaian kurang, yaitu 1 poin.

10) Berdasarkan Renstra FEB USU Tahun 2015-2019 telah disebutkan analisa permasalahan yang dihadapi sehubungan dengan tenaga kependidikan, antara lain yaitu kualifikasi pendidikan, kompetensi, etos kerja, dan integritasnya masih rendah, sebaran tenaga kependidikan tidak sesuai dengan kebutuhan yang berakibat kepada pelayanan 
yang tidak optimal. Telah pula dicantumkan upaya-upaya yang akan dilakukan sebagai solusinya, antara lain dengan membangun komitmen tenaga kependidikan, meningkatkan jumlah pegawai administrasi yang mengikuti pendidikan S1, S2, dan diklat. Berdasarkan Renop FEB USU Tahun 20152019 juga telah disebutkan target dan indikator kinerja utama yang sasaran ke-5 nya ialah memiliki SDM Tenaga Kependidikan yang berkemampuan dan berketrampilan tinggi dengan kegiatan antara lain adalah melakukan pelatihan peningkatan mutu pelayanan tenaga kependidikan dengan indikator kinerja kegiatan adalah terlaksananya pelatihan peningkatan mutu pelayanan yang ditargetkan dengan adanya pelaksanakan setiap tahunnya. Selanjutnya adalah peningkatan kualitas pelayanan tenaga kependidikan dengan kegiatan mendorong tenaga kependidikan untuk meningkatkan jenjang pendidikan ke S1 dengan indikator kinerja kegiatan ialah jumlah staf yang memiliki pendidikan S1 dari baseline 20 orang ditargetkan bertambah 1 orang setiap tahunnya. Sehingga berdasarkan arah kebijakan, FEB USU layak mendapatkan penilaian baik, point 3 .

Berdasarkan implementasi kebijakan, kesempatan belajar/ pelatihan tenaga kependidikan FEB USU hanya diberikan pada kegiatan-kegiatan pelatihan yang diinisiasi dan anggarannya berasal dari Biro Rektorat USU, antara lain pelatihan bidang keuangan, akademik, kearsipan dan lain sebagainya. Namun, FEB USU sama sekali tidak memiliki analisa kebutuhan dan perencanaan dalam kebijakan pemberian kesempatan belajar/ pelatihan di luar kegiatan dari Biro Rektorat USU. Sebagai contoh, berdasarkan observasi, peneliti menemukan kurangnya pengetahuan tenaga kependidikan bidang akademik dalam penggunaan aplikasi microsoft office khususnya excel dalam rutinitas pekerjaan sehari-hari yang dapat memudahkan dalam pekerjaan dan pelaporan. Biro Rektorat USU memang pernah mengadakan pelatihan microsoft office dan meminta perwakilan dari FEB USU sebagai pesertanya, dan FEB USU telah mengirimkan dua orang tenaga kependidikan untuk mengikuti pelatihan tersebut. Yang menjadi perhatian peneliti ialah mengapa pengambil kebijakan di FEB USU tidak mengajukan permohonan kepada Biro Rektorat USU agar bisa mengikutsertakan lebih banyak peserta dari FEB USU khususnya bagi tenaga kependidikan yang lemah dalam kemampuan penggunaan microsoft office, atau mengapa FEB USU tidak mengadakan pelatihan sejenis di lingkungan FEB USU sendiri? Peneliti menyimpulkan bahwa memang sangat minim perhatian dari pengambil kebijakan dalam upaya peningkatan kualifikasi dan kompetensi tenaga kependidikan di lingkungan FEB USU. FEB USU juga tekesan sulit dalam pemberian fasilitas pendanaan untuk upaya peningkatan kualifikasi dan kompetensi tenaga kependidikan.

Contoh yang lebih buruk adalah dengan tidak diberikannya izin melanjutkan pendidikan kepada peneliti yang mengajukan surat izin melanjutkan pendidikan yang pendanaannya berasal dari uang pribadi dan dengan pertimbangan kuliah di lakukan di luar jam kerja dan tidak meninggalkan tugas dan tanggung jawab pekerjaan. Izin tersebut ditolak dengan beberapa alasan yang sangat tidak rasional yaitu yang pertama karena peneliti dibutuhkan sebagai tenaga arsiparis, padahal faktanya peneliti tidak diberikan penugasan maupun kewenangan sebagai tenaga arsiparis dan jurusan yang ditempuh adalah administrasi pendidikan yang jelasjelas sangat berhubungan dengan pekerjaan rutinitas tenaga kependidikan. Alasan lainnya ialah dikarenakan peneliti dianggap baru dan belum menunjukkan pengabdiannya, padahal 
peneliti sudah lebih dari sepuluh tahun bertugas sebagai PNS, lebih dari lima tahun bertugas di Universitas Sumatera Utara.

Contoh lain dengan dicoretnya surat usulan mengikuti ujian pencantuman ijazah S2 salah satu tenaga kependidikan oleh Wakil Dekan II meskipun surat tersebut sebelumnya sudah diparaf oleh Kasubbag. TU.

Berdasarkan data kepegawaian juga di ketahui bahwa terdapat 13 tenaga kependidikan yang memiliki ijazah yang lebih tinggi dari ijazah yang diakui dalam status kepegawaiannya, karena beberapa alasan yang merupakan kebijakan internal USU namun tidak sesuai dengan kebijakan lembaga pendidikan tinggi. Studi banding untuk peningkatan kualifikasi dan kompetensi tenaga kependidikan menjadi suatu hal dianggap tidak perlu oleh para pengambil kebijakan Fakultas Ekonomi dan Bisnis USU karena dianggap bertentangan dengan prinsip efisiensi anggaran. Selama dua tahun terakhir, belum pernah ada studi banding yang khusus diadakan untuk peningkatan kualifikasi dan kompetensi tenaga kependidikan. Sehingga, berdasarkan penilaian berdasarkan implementasi kebijakan, FEB USU dalam upaya peningkatan kualifikasi dan kompetensi tenaga kependidikan hanya layak mendapat penilaian kurang, yaitu 1 poin.

Berdasarkan hasil survey tingkat kepuasan terhadap seluruh (52 orang) tenaga kependidikan, hanya 42 tenaga kependidikan memberi jawaban, dan terhadap upaya FEB USU dalam meningkatkan kualifikasi dan kompetensi tenaga kependidikan yang menjawab sangat baik/baik dalam hal pemberian kesempatan belajar/pelatihan sebanyak 8 orang (19\%), dalam hal pemberian fasilitas termasuk dana sebanyak 3 orang $(7 \%)$, dalam hal kejelasan jenjang karir sebanyak 10 orang (24\%), dalam hal studi banding sebanyak 2 orang (5\%).
11) Berdasarkan hasil observasi dan wawancara dengan beberapa tenaga kependidikan Fakultas Ekonomi dan Bisnis USU, diketahui bahwa Fakultas Ekonomi dan Bisnis USU tidak memiliki intrumen survei kepuasan tenaga kependidikan terhadap sistem pengelolaan sumber daya manusia, sehingga, berdasarkan penilaian pada Matrik Penilaian Borang dan Evaluasi Diri BAN PT, Fakultas Ekonomi dan Binis USU akan mendapatkan penilaian sangat kurang, yaitu 0 poin.

12) Berdasarkan hasil observasi dan wawancara dengan beberapa tenaga kependidikan Fakultas Ekonomi dan Bisnis USU, tidak ada pelaksanaan survei kepuasan tenaga kependidikan terhadap sistem pengelolaan sumber daya manusia, sehingga, berdasarkan penilaian pada Matrik Penilaian Borang dan Evaluasi Diri BAN PT, Fakultas Ekonomi dan Binis USU akan mendapatkan penilaian sangat kurang, yaitu 0 poin.

13) Berdasarkan hasil temuan pada indikator variabel nomor 11 dan 12 diatas, maka berdasarkan penilaian pada Matrik Penilaian Borang dan Evaluasi Diri BAN PT, Fakultas Ekonomi dan Bisnis USU akan mendapatkan penilaian sangat kurang, yaitu 0 poin.

14) Berdasarkan hasil observasi dan wawancara tidak terdapat kebijakan khusus yang tertulis tentang penggunaan dana operasional yang berhubungan dengan tenaga kependidikan. Namun hal tersebut sudah dimasukkan secara umum berdasarkan program kerja pada Renstra FEB USU Tahun 2015-2019, antara lain dengan penambahan ketersediaan ruang tenaga kependidikan untuk memenuhi standar dikti (Renstra FEB USU Tahun 2015-2019, halaman 33), mempersiapkan SDM yang bermutu, meningkatkan kualifikasi dan kompetensi, 


\section{Jurnal Serunai Administrasi Pendidikan \\ Vol 9, No. 1, Maret 2020 \\ e-ISSN 2620-9209}

menempuh jenjang pendidikan tinggi sesuai dengan tuntutan keahlian, menyiapkan teknisi, analis dan laboran yang kompeten (Renstra FEB USU Tahun 2015-2019, halaman 44), dan lain sebagainya. Sehingga berdasarkan arah kebijakan, FEB USU layak mendapatkan penilaian baik, 3 poin dalam hal penggunaan dana operasional yang berhubungan dengan tenaga kependidikan.

Namun, berdasarkan hasil observasi dan wawancara mengenai penggunaan dana operasional sehubungan dengan tenaga kependidikan, berlakunya prinsip penghematan anggaran yang diterapkan oleh para pengambil kebijakan berdampak kepada minimnya penggunaan dana operasional khususnya untuk kegiatan-kegiatan yang berhubungan dengan tenaga kependidikan. Sebagai contoh adalah ketiadaan dukungan para pengambil kebijakan untuk kegiatan pembenahan arsip meskipun sudah ada arahan maupun pelatihan-pelatihan yang diinisiasi oleh pihak Biro Rektorat USU untuk mendukung pembenahan arsip di lingkungan fakultas. Sampai penelitian ini diselesaikan, belum ada satu pun rekomendasi kebijakan maupun pengadaan kelengkapan pembenahan kearsipan yang direalisasi oleh para pengambil kebijakan fakultas dengan alasan ketiadaan anggaran, meskipun pada kenyataannya banyak anggaran yang dikembalikan ke Biro Rektorat USU dikarenakan tidak digunakan.

Contoh lain ialah tidak disediakannya dana operasional untuk mengikuti kegiatan peringatan hari kemerdekaan di lingkungan USU selama 2 tahun berturut-turut. Tidak disediakannya dana untuk kegiatan outbond tenaga kependidikan.

Sehingga, berdasarkan implementasi kebijakan, FEB USU hanya layak mendapatkan penilaian kurang, yaitu 1 poin. Berdasarkan hasil survey tingkat kepuasan terhadap seluruh (52 orang) tenaga kependidikan, hanya 42 tenaga kependidikan memberi jawaban, dan terhadap penggunaan dana operasional sehubungan dengan tenaga kependidikan yang menjawab sangat baik/baik dalam hal gaji dan upah sebanyak 14 orang (33\%), dalam hal investasi sarana dan prasarana sebanyak 9 orang $(21 \%)$, dalam hal peningkatan kualitas SDM sebanyak 16 orang $(38 \%)$.

15) Berdasarkan hasil observasi dan wawancara, dalam arah kebijakan sistem pengelolaan prasarana dan sarana di FEB USU sebagai bagian dari lembaga pendidikan di bawah naungan pemerintah harus berpedoman pada aturan yang berlaku di lembaga pemerintahan yang berarti secara penilaian arah kebijakan maka FEB USU layak mendapat penilaian baik, 3 poin. Namun dalam implementasi kebijakan FEB USU dinilai masih banyak kekurangan. Sebagai contoh dalam hal pengembangan sarana dan prasarana khususnya yang berhubungan dengan tenaga kependidikan sulit untuk direalisasikan. Seperti permohonan pergantian komputer, pengadaan scanner, pengadaan UPS, pengadaan perlengkapan penunjang pembenahan kearsipan, dan lain sebagainya penunjang kegiatan keadministrasian tenaga kependidikan belum pernah terealisasi. Hal tersebut jadi semakin salah terlebih jika mengingat besarnya anggaran yang disediakan oleh pihak rektorat USU namun tidak dipergunakan secara maksimal dan dikembalikan ke Biro Rektorat USU.

Pada pencatatan, sistem pengelolaan prasarana dan sarana dinilai sudah cukup baik karena sudah menggunakan aplikasi pencatatan dan pelaporan yang berlaku di lingkungan USU.

Implementasi kebijakan penetapan penggunaan khususnya yang berhubungan dengan tenaga kependidikan, sistem 
pengelolaan prasarana dan sarana FEB USU masih terkesan satu arah, yaitu sesuai dengan keinginan pimpinan/ pengambil kebijakan yang bertanggung jawab dan kurang menerima aspirasi dari pengguna (tenaga kependidikan) dengan alasan efisiensi anggaran.

Dalam hal keamanan, sistem pengelolaan prasarana dan sarana FEB USU juga dianggap kurang, salah satunya karena adanya kesalahan pemikiran bahwa CCTV difungsikan sebagai alat pengawasan oleh pimpinan kepada tenaga kependidikan, bukan sebagai alat bantu bagi petugas keamanan yang jumlahnya terbatas untuk mempermudah dalam menjaga keamanan lingkungan FEB USU.

Keselamatan penggunaan pada sistem pengelolaan prasarana dan sarana FEB USU dinilai sudah relatif cukup karena hanya sedikit prasarana dan sarana yang bisa membahayakan keselamatan penggunaan. Namun ada satu kasus kerusakan plafon yang sementara diberi penyangga untuk menghindari plafon yang ambruk dan menimpa orang-orang di bawahnya.

FEB USU dianggap belum maksimal dalam hal pemeliharaan dan perbaikan khususnya untuk sarana dan prasarana yang berhubungan dengan tenaga kependidikan, karena masih ada prasarana dan sarana yang tersedia kurang terpelihara dan kurang perbaikan. Sebagai contoh, kunci pintu kamar mandi/ toilet pagawai di lantai 2 gedung administrasi yang sudah sekian lama rusak namun tidak diperbaiki. Sabun di kamar mandi/ toilet pegawai yang tidak disediakan. Namun dalam hal kebersihan dinilai sudah baik karena FEB USU sudah bekerjasama dengan perusahaan penyedia jasa kebersihan.

Secara keseluruhan, penilaian implementasi kebijakan sistem pengelolaan prasarana dan sarana pada FEB USU hanya layak mendapatkan penilaian kurang, yaitu 1 poin.
Berdasarkan hasil survey tingkat kepuasan terhadap seluruh (52 orang) tenaga kependidikan, hanya 42 tenaga kependidikan memberi jawaban, dan terhadap sistem pengelolaan sarana dan prasarana sehubungan dengan tenaga kependidikan yang menjawab sangat baik/ baik dalam hal pengembangan dan pencatatan sebanyak 13 orang (31\%), dalam hal penetapan penggunaan sebanyak 13 orang (31\%), dalam hal keamanan dan keselamatan penggunaan sebanyak 9 orang $(21 \%)$, dalam hal pemeliharaan/ perbaikan/ kebersihan sebanyak 9 orang (21\%), dalam hal akses informasi dan transparansi sebanyak 9 orang (21\%), dalam hal kecukupan dan mutu sebanyak 10 orang (24\%).

16) Berdasarkan hasil observasi dan wawancara, serta isi Renstra dan Renop FEB USU Tahun 2015-2019, arah kebijakan FEB USU dalam memenuhi tingkat kecukupan dan mutu prasarana dinilai sudah baik, 3 poin. Antara lain seperti dicantumkan pada halaman 33 Renstra FEB USU Tahun 2015-2019 tentang upaya pemenuhan kecukupan ruangan tenaga kependidikan agar dapat memenuhi standar Dikti. Demikian juga pada Renstra FEB USU Tahun 2015-2019 halaman 37, disebutkan bahwa strategi pengembangan salah satunya adalah dengan melengkapi sarana dan prasarana.

Berdasarkan hasil wawancara mengenai implementasi kebijakan tersebut dinilai masih kurang karena adanya pola pikir pimpinan/ pengambil kebijakan yang menerapkan prinsip penggunaan minimal anggaran belanja adalah suatu prestasi, sehingga banyak anggaran fakultas yang dikembalikan ke Biro Rektorat USU karena tidak dipergunakan. Keluhan dari tenaga kependidikan terhadap kecukupan mutu dan prasarana penunjang pekerjaan sebagian besar diabaikan. Salah satunya adalah pengalaman pribadi peneliti yang sudah hampir dua tahun terhitung 
Januari 2018 mengajukan permohonan pengadaan scanner namun sampai Agustus 2019 masih belum juga direalisasi.

Contoh lain ialah sering terjadinya kerusakan pada instalasi kelistrikan dan air, tidak tersedianya sabun cuci tangan di kamar mandi pegawai, tidak difasilitasinya ketersediaan kebutuhan pantry/ dapur pegawai.

Sehingga berdasarkan penilaian implementasi kebijakan terhadap kecukupan mutu sarana dan prasarana FEB USU hanya layak mendapat penilaian kurang, yaitu 1 poin.

17) Berdasarkan hasil observasi dan wawancara mengenai arah kebijakan berdasarkan Renstra dan Renop FEB USU Tahun 2015-2019, diketahui bahwa FEB USU sudah mencantumkan pengoptimalan sistem informasi dan melengkapi sarana dan prasarana pada strategi pengembangan, serta melengkapi dan memberdayakan sistem informasi dan digitalisasi pada program kerja sebagaimana tercantum pada halaman 37 \& 38 Renstra FEB USU Tahun 2015-2019. Demikian pula pada tabel program kerja Renstra FEB USU nomor 8 halaman 46, program studi diharapkan melengkapi sistem informasi dan digitalisasi melalui kebijakan revitalisasi sistem informasi dengan kegiatan antara lain mengintegrasikan sistem informasi antar unit dan pendelegasian konten website ke program studi di lingkungan fakultas, mengembangkan sistem informasi yang dapat diakses secara internasional, dan menyempurnakan sistem informasi dan fasilitas dalam administrasi akademik dan umum, pengelolaan sarana dan prasarana yang transparan, akurat, dan cepat. Oleh karena itu penilaian arah kebijakan FEB USU layak mendapatkan penilaian baik, 3 poin.

Berdasarkan hasil observasi dan wawancara tentang implementasi kebijakan, diketahui bahwa kualitas jaringan internet yang terhubung dengan komputer pada setiap bagian administrasi sudah sangat baik, termasuk juga dengan kualitas software basis data sudah cukup baik dalam mempermudah pekerjaan. Software basis data yang digunakan FEB USU merupakan hasil rancangan Pusat Sistem Informasi USU yang digunakan di seluruh lingkungan USU. Tapi menurut observasi dan pengalaman peneliti memang masih ada beberapa hal dari software basis data tersebut yang belum sesuai fungsi dan kebutuhannya dengan rutinitas pekerjaan administrasi, khususnya pada aplikasi Sistem Informasi Akademik (SIA). Perancang software basis data masih terkesan hanya merancang sistem tanpa mendengar langsung kebutuhan tenaga kependidikan selaku pelaksana administrasi sehari-hari di lapangan. Perancang software basis data juga terkesan kurang melakukan studi banding ke perguruan tinggi atau instansi lainnya dalam penggunaan dan perancangan softwaresoftware basis data yang bisa membantu dan mempermudah pekerjaan administrasi. Peneliti sering melakukan koreksi terhadap aplikasi SIA melalui grup whatsapp bagian akademik USU. Antara lain, tidak sesuainya data status mahasiswa di aplikasi SIA dengan data mahasiswa di situs forlap dikti, tidak akuratnya data evaluasi mahasiswa, tidak adanya optimalisasi hasil evaluasi SIA dalam mendukung peraturan dan kebijakan yang berlaku di lingkungan USU. Sebagai contoh, peneliti pernah melakukan pemeriksaan manual terhadap keakuratan data SIA dengan data forlap dikti lebih dari 1510 mahasiswa S1 Akuntansi Ekstensi pada Juli 2019, dengan hasil 25\% mahasiswa tidak teregistrasi di forlap dikti, dan $45 \%$ mahasiswa yang sudah lulus belum teregistrasi lulus. Yang menjadi permasalahan utama ialah PSI USU tidak memiliki sistem yang bisa mengkoreksi kesesuaian data SIA dengan data forlap dikti dan terpaksa harus menugaskan tenaga 
kependidikan memeriksa data mahasiswa tersebut satu persatu.

Akses terhadap data yang relevan dan cepat masih terbatas hanya pada data yang tersedia pada aplikasi, sedangkan pada data-data yang tidak ditampilkan di aplikasi akan sulit mendapatkannya. Hal tersebut dikarenakan masih kurangnya penerapan sistem pelaporan dan tabulasi data di kalangan tenaga kependidikan dan bukan pula menjadi perhatian para pengambil kebijakan di lingkungan FEB USU. Sebagai contoh, di bagian akademik sulit untuk mendapatkan jawaban berapa jumlah mahasiswa yang melakukan seminar proposal maupun sidang skripsi dalam satu semester berjalan. Atau data berapa kali dosen A sebagai penguji dan berapa jumlah mahasiswa yang diujinya dalam satu semester. Atau data berapa persentase kelulusan mahasiswa di mata kuliah A. Ketidakpedulian pengambil kebijakan maupun tenaga kependidikan FEB USU terhadap pelaporan data-data tersebut membuktikan bahwa tidak adanya evaluasi terhadap pelaksanaan pendidikan secara berkala di lingkungan FEB USU sejauh ini.

Berdasarkan hal-hal tersebut di atas, maka implementasi kebijakan sistem informasi dan fasilitas di FEB USU hanya layak mendapatkan penilaian cukup, yaitu 2 poin.

18) Berdasarkan hasil observasi dan wawancara mengenai kebijakan tertulis berdasarkan Renstra dan Renop FEB USU Tahun 2015-2019 dalam sistem informasi untuk pengelolaan sarana dan prasarana sehubungan dengan tenaga kependidikan, FEB USU dinilai sudah baik, 3 poin dengan pertimbangan alasan yang sama dengan alasan penilaian sistem informasi dan fasilitas FEB USU. Pada implementasinya sistem informasi sarana dan prasarana memang sudah menggunakan aplikasi untuk pendataan dan pelaporan sehubungan dengan kewajiban atas penggunaan keuangan negara kepada pihak pihak Biro Rektorat USU. Namun aplikasi tersebut belum sebagai sistem informasi yang terbuka untuk semua tenaga kependidikan sebagai pengguna sarana dan prasarana karena hanya bisa diakses oleh bagian-bagian tertentu yang dianggap berkepentingan. Sehingga, berdasarkan implementasi kebijakannya FEB USU hanya layak mendapatkan penilaian kurang, yaitu 1 poin.

\section{KESIMPULAN}

Berdasarkan hasil pembahasan di atas, gambaran manajemen tenaga kependidikan FEB USU dalam mendukung pencapaian standar nasional pendidikan adalah sebagai berikut;

1) Berdasarkan 18 indikator penilaian yang menggunakan poin-poin pada Instrumen Akreditasi Perguruan Tinggi BAN-PT, Buku VI, Matrik Penilaian Borang dan Evaluasi Diri, Badan Akreditasi Nasional Perguruan Tinggi, Jakarta 2011, pada poin-point yang berhubungan dengan manajemen tenaga kependidikan, dihasilkan nilai kebijakan FEB USU sebesar 41 dari maksimal 72 poin (ratarata 2,28 poin/ cukup), dan nilai implementasi kebijakan FEB USU sebesar 16 poin dari maksimal 68 poin (rata-rata $0,94 /$ kurang).

2) Berdasarkan hasil penilaian disimpulkan bahwa manajemen tenaga kependidikan FEB USU dalam mendukung pencapaian standar nasional pendidikan cukup dalam kebijakan namun kurang dalam implementasi.

3) Kurangnya komitmen para pengambil kebijakan di lingkungan FEB USU dalam mewujudkan visi, misi, renstra dan renop FEB USU, khususnya yang berhubungan dengan tenaga kependidikan. 


\section{DAFTAR PUSTAKA}

Abdullah, Nazaruddin. 2011. Al-Quran dan Manajemen Pendidikan. Bandung: Citapustaka Media Perintis.

Amiruddin, Wahyuli. 2010. Administrasi Pendidikan. Bandung: Citapustaka Media Perintis.

Asrul, Syafaruddin. 2014. Manajemen Kepengawasan Pendidikan. Bandung: Citapustaka Media.

Badan Akreditasi Nasional Perguruan Tinggi, 2011. Buku I Naskah Akademik. Akreditasi Institusi Perguruan Tinggi. Jakarta, (Online), (https://www.banpt.or.id/download_instrumen , diakses 3 Maret 2019)

Badan Akreditasi Nasional Perguruan Tinggi, 2011. Buku II Standar dan Prosedur. Akreditasi Institusi Perguruan Tinggi. Jakarta, (Online),

(https://www.banpt.or.id/download_instrumen , diakses 3 Maret 2019)

Badan Akreditasi Nasional Perguruan Tinggi, 2011. Buku III Pedoman Penyusunan Borang. Akreditasi Institusi Perguruan Tinggi. Jakarta, (Online),

(https://www.banpt.or.id/download_instrumen , diakses 3 Maret 2019)

Badan Akreditasi Nasional Perguruan Tinggi, 2011. Buku IV Pedoman Penyusunan Borang. Akreditasi Institusi Perguruan Tinggi. Jakarta, (Online),

(https://www.banpt.or.id/download_instrumen , diakses 3 Maret 2019)

Badan Akreditasi Nasional Perguruan Tinggi, 2011. Buku V Pedoman Penilaian Borang dan Evaluasi Diri. Akreditasi Institusi Perguruan Tinggi. Jakarta, (Online), (https://www.banpt.or.id/download_instrumen , diakses 3 Maret 2019)

Badan Akreditasi Nasional Perguruan Tinggi, 2011. Buku VI Matrik Penilaian Borang dan Evaluasi Diri. Akreditasi Institusi Perguruan
Tinggi.

Jakarta,

(Online),

(https://www.banpt.or.id/download_instrumen , diakses 3 Maret 2019)

Badan Akreditasi Nasional Perguruan Tinggi, 2011. Buku VII Pedoman Asesmen Lapangan. Akreditasi Institusi Perguruan Tinggi. Jakarta, (Online),

(https://www.banpt.or.id/download_instrumen , diakses 3 Maret 2019)

Candra, Muhammad. 2005. Dasar-dasar Manajemen. Medan: Perdana Publishing.

Fakultas Ekonomi dan Bisnis Universitas Sumatera Utara, 2015. Rencana Strategis (Renstra) Fakultas Ekonomi dan Bisnis USU 2015-2019. Medan.

Fakultas Ekonomi dan Bisnis Universitas Sumatera Utara, 2015. Rencana Operasional (Renop) Fakultas Ekonomi dan Bisnis USU 2015-2019. Medan.

Hadijaya Yusuf. 2012. Administrasi Pendidikan. Medan: Perdana Publishing.

Hasibuan, Malayu S.P. 2013. Manajemen Sumber Daya Manusia. Cetakan Ketujuh Belas. Jakarta. PT. Bumi Aksara.

Muhaimin, dkk. 2012. Manajemen Pendidikan Jakarta: Prenada Media Group.

Peraturan Pemerintah Republik Indonesia Nomor 19 Tahun 2005 Tentang Standar Nasional Pendidikan, (Online), (http://luk.staff.ugm.ac.id/atur/Kepmen057-O2007.pdf, diakses 3 Maret 2019).

Peraturan Pemerintah Republik Indonesia Nomor 32 Tahun 2013 Tentang Perubahan atas Peraturan Pemerintah Nomor 19 Tahun 2005 Tentang Standar Nasional Pendidikan, (Online),

Peraturan Menteri Pendidikan dan Kebudayaan Republik Indonesia Nomor 49 tahun 2014 Tentang Standar Nasional Pendidikan Tinggi, (Online), (http://faperta.ugm.ac.id/2014/site/fokus/pdf/p 
ermen_tahun2014_nomor049.pdf, diakses 3 Maret 2019).

Peraturan Menteri Pendidikan Dan Kebudayaan Republik Indonesia Nomor 49 Tahun 2014 Tentang Standar Nasional Pendidikan Tinggi, (Online),

(http://faperta.ugm.ac.id/2014/site/fokus/pdf/p ermen_tahun2014_nomor049.pdf, diakses 3 Maret 2019)

Sagala, Syaiful. 2011. Kemampuan Profesional Guru dan Tenaga Kependidikan. Bandung: Alfabeta.

Salim, Syahrum. 2011. Metode Penelitian Kualitatif. Bandung: Citapustaka Media.

Siahaan, Amiruddin. 2010. Ilmu Pendidikan dan Masyarakat Belajar. Bandung: Citapustaka Media Perintis.

Susmaini, Muhammad. 2007. Teori Manajemen. Bandung: Citapustaka Media.

Syafaruddin, Asrul. 2014. Manajemen Kepengawasan Pendidikan. Bandung: Citapustaka Media.

Syamsuddin, Udin. 2009. Perencanaan Pendidikan. Bandung: PT Remaja Rosdakarya.

Undang-undang Dasar Negara Republik Indonesia Tahun 1945, (Online), (http://jdih.pom.go.id/uud1945.pdf, diakses 3 Maret 2019).

Undang-undang Nomor 2 Tahun 1989 tentang Sistem Pendidikan Nasional, (Online), (http://luk.staff.ugm.ac.id/atur/UU21989Sisdiknas.pdf, diakses 3 Maret 2019).

Undang-undang Republik Indonesia Nomor 20 tahun 2003 Tentang Sistem Pendidikan Nasional, (Online), (https://kelembagaan.ristekdikti.go.id/wpcontent/uploads/2016/08/UU_no_20_th_2003 .pdf, diakses 3 Maret 2019).
Undang-undang Republik Indonesia Nomor 12 tahun 2012 Tentang Pendidikan Tinggi, (Online),

(http://diktis.kemenag.go.id/prodi/dokumen/U U-Nomor-12-Tahun-2012-ttg-PendidikanTinggi.pdf, diakses 3 Maret 2019). 